УдК 343.985.7

\author{
М. А. Погорецький, Д. Б. Сергеєва
}

\title{
СПІВВІДНОШЕННЯ КРИМІНАЛІСТИЧНОЇ МЕТОДИКИ Й ОРГАНІЗАЦІЇ КРИМІНАЛЬНОГО ПРОВАДЖЕННЯ
}

Постановка проблеми. Вирішення завдань кримінального провадження, що полягають у захисті особи, суспільства та держави від кримінальних правопорушень, охороні прав і законних інтересів учасників кримінального провадження, а також забезпеченні швидкого, повного й неупередженого розслідування та судового розгляду з тим, щоб кожний, хто вчинив кримінальне правопорушення, був притягнутий до відповідальності в міру своєї вини, жоден невинуватий не був обвинувачений або засуджений i жодна особа не була піддана необгрунтованому процесуальному примусу й щоб до кожного учасника кримінального провадження була застосована належна правова процедура, потребує як належної організації діяльності сторін кримінального провадження та суду (слідчого судді), так і використання ними сучасних криміналістичних методик.

Аналіз останніх досліджень і публікацій. Ураховуючи те, що криміналістична методика Й організація кримінального провадження $є$ фундаментальними категоріями криміналістики, мають велике значення для розвитку теорії і практики, вони були предметом дослідження як у радянську добу, так і в пострадянський період вітчизняних і зарубіжних криміналістів: Л.Є. Ароцкера, Т.В. Авер'янової, В.П. Бахіна, Р.С. Бєлкіна, О.М. Васильєва, Т.В. Варфоломеєвої, І.О. Возгріна, А.Ф. Волобуєва, С.О. Голунського, В.Г. Гончаренка, В.І. Громова, В.А. Журавля, Є.П. Іщенка, Н.I. Клименко, I.I. Когутича, В.П. Корж, В.Є. Корнукова, В.Я. Колдіна, О.Н. Колесніченка, В.І. Комісарова, В.О. Коновалової, В.С. Кузьмічова, О.М. Ларіна, В.В. Лисенка, В.К. Лисиченка, Є.Д. Лук'янчикова, Г.А. Матусовського, В.О. Образцова, О.В. Одерія, І.Ф. Пантелєєва, М.О. Селіванова, В.Г. Танасевича, О.В. Таран, В.В. Тіщенка, С.С. Чернявського, Ю.М. Чорноус, Б.М. Шавера, В.М. Шевчука, В.Ю. Шепітька, А.В. Шмоніна, Б.В. Щура, М.П. Яблокова й інших.

Проте до цього часу в теорії криміналістики не склалося єдності думок щодо визначення поняття цих категорій, ї змісту і співвідношення. У науці та практичній діяльності нерідко ототожнюються окремі із цих категорій, підміняються одна одною або ж укладається в них зміст, який не відповідає їх сутності, що негативно позначається на наукових розробках криміналістичної методики й організації кримінального провадження, на навчальному процесі та правозастосовній діяльності. 
Передусім зазначимо, що термін «організація кримінального провадження» не $є$ поширеним у криміналістиці, а тому перед формулюванням мети цієї статті та викладенням основного матеріалу дослідження вважаємо доцільним зауважити, що термін «організація» більшістю криміналістів вживається лише щодо досудового розслідування, а окремими фахівцями й щодо судових стадій чи діяльності окремих суб’єктів кримінального процесу. Враховуючи те, що термін «кримінальне провадження» охоплює усі стадії кримінального провадження і діяльність усіх суб'єктів, які ведуть кримінальний процес чи йому сприяють (захисник, експерт та ін.), а також те, що на усіх стадіях кримінального провадження може застосовуватися і криміналистична методика і організація, цілком логічно, на наш погляд, вживати термін «організація кримінального провадження» як родове поняття та відповідні видові поняття (організація досудового розслідування, організація захисту, організація обшуку тощо).

Зважаючи на зазначене, метою статті є авторське визначення співвідношення криміналістичної методики й організації кримінального провадження.

Виклад основного матеріалу дослідження. В теорії криміналістики та правозастосовній діяльності використовуються різні терміни для позначення криміналістичної методики: власне «криміналістична методика» [1, с. 411; 2, с. 343; 3, с. 423], «методика розслідування злочинів» [4, с. 358-364; 5, с. 3-5], «методика з розслідування злочинів» [6, с. 422], «криміналістична методика розслідування» [7, с. 481], «методика розслідування окремих видів злочинів» [8, с. 247], «окрема методика» [9, с. 42-56], «методика підтримання державного обвинувачення» $[10$, с. 213$]$, «методика захисту» $[11$, с. 47], «методика судового розгляду» [12, с. 150-171], «методика судової діяльності» [11, с. 124], «методика судового розгляду кримінальних справ» [13, с. 298-307; 14, с. 247] тощо.

Результати аналізу наведеної термінологіi, їі понять і їх змісту дають підстави для висновку, що спільним для цих термінів є слово «методика», яке, виходячи з його етимологічного значення, означає сукупність взаємопов'язаних способів і прийомів доцільного проведення будь-якої роботи [15, с. 664] (у тому числі й кримінальної процесуальної діяльності - М. П. і Д. С.).

Варто зазначити, що, незважаючи на те що кримінальний процес (кримінальне судочинство) й передусім його змагальна форма реалізуються через три основні кримінальні процесуальні функціі: обвинувачення, захист і вирішення кримінальної справи (правосуддя), які є відносно самостійними напрямами кримінальної процесуальної діяльності та які залежно від форми (моделі, типу) кримінального процесу мають своє змістове навантаження, перші наукові праці криміналістів, що з'явилися в 20-30-ті роки минулого століття, були присвячені лише методиці розслідування окремих видів злочинів [9; 16;17], тобто діяльності слідчого як одного із суб'єктів функції обвинувачення за чинним Кримінальним процесуальним кодексом (далі - КПК) України (\$ 2, ст. 40). I лише в 70-90-ті роки минулого століття 3'явилися одиничні роботи криміналістів, присвячені науковим i практичним проблемам методики судового розгляду [12, с. 150-171], методики захисту [11, с. 131], методики державного обвинувачення [10]. Наукові ідеї щодо розробки зазначених методик набули свого розвитку в наукових працях більш пізнього часу $[18 ; 19 ; 11 ; 20 ; 21 ; 22 ; 23$ тощо]. 
Підтримуючи ідею щодо правомірності існування зазначених методик, Б.В. Щур висловив думку стосовно розуміння криміналістичної методики у вузькому та широкому значеннях. Зокрема, у вузькому значенні криміналістична методика - це методика розслідування окремих видів злочинів. Сферою ii діяльності $є$ процеси розслідування, і звернена вона до діяльності органів досудового розслідування. Фактично мова йде про класичне розуміння криміналістичної методики. У широкому розумінні криміналістична методика, на думку автора, - це не лише методика розслідування, а й методика судового розгляду кримінальних справ тієї чи іншої категорії, методики кримінального захисту або державного обвинувачення. У цьому випадку сфера криміналістичної методики, на думку автора, є розширеною [24, с. 95].

Як нам видається, така позиція автора потребує уточнення. Уважаємо доцільним визначати криміналістичну методику як родове поняття. Виходячи з трьох основних функцій кримінального процесу та його вітчизняної форми, видовими методиками є методика обвинувачення, методика захисту, методика судового розгляду. У кожній із цих видових методик доцільно виділити підвидові чи окремі методики залежно від критеріїв їх класифікації. Наприклад, у методиці обвинувачення можемо виділити такі підвидові чи окремі методики: методика розслідування окремих видів злочинів; методика процесуального керівництва; методика підтримання обвинувачення в суді тощо. Практичне значення мають і комплексні методики. Кожна з наведених методик потребує розробки іiі структури з урахуванням передусім сучасної моделі вітчизняного кримінального процесу, який із набранням чинності КПК України 2012 р. концептуально змінив свою форму, розширивши межі реалізації засади змагальності в досудовому розслідуванні та в ході судового розгляду кримінальних проваджень. Відповідно до ч. 6 ст. 22 КПК України, на суд покладається обов’язок створювати необхідні умови для реалізації сторонами їхніх процесуальних прав і виконання процесуальних обов'язків, зберігаючи при цьому об’єктивність і неупередженість. Тому, розробляючи зазначені методики, варто виходити із законодавчих новел, які суттєво відрізняються від КПК України 1960 р. та чинного КПК РФ, норми якого є основою для розробки російськими криміналістами наукових положень криміналістичної методики, що продовжують суттєво впливати на вітчизняну криміналістичну доктрину.

3 огляду на зазначене, вважаємо необгрунтованою точку зору I.I. Когутича, який до змісту методики судового розгляду кримінальних справ включає й алгоритм діяльності державного обвинувача та захисника [13, с. 247, 248]. Як уже нами було зазначено, алгоритм діяльності державного обвинувача та захисника на судових стадіях процесу є частиною видових методик обвинувачення й захисту.

На нашу думку, для подальшої розробки проблемних питань криміналістичних методик обвинувачення, захисту й судового розгляду, яким у теорії криміналістики за досліджуваний період присвячені лише одиничні праці, методологічною основою могли б стати наукові підходи до розробки криміналістичної методики розслідування злочинів, якій присвячено багато наукових публікацій, у тому числі й монографічного характеру, хоча й більшість ї питань продовжують залишатися дискусійними й дотепер, що потребує й у межах статті їх авторського висвітлення. 
Варто зазначити, що в теорії криміналістики висловлюються думки, що термін «криміналістична методика розслідування злочинів» позначає самостійний розділ криміналістики. Термін «окрема криміналістична методика» являє систему (комплекс) науково-практичних рекомендацій щодо організації та здійснення розкриття, розслідування злочинів конкретного виду й запобігання їм, а термін «криміналістична методика розслідування» - це окрема науково обгрунтована та практично перевірена порада (пропозиція) для покращення роботи з розслідування [25, с. 203; 26, с. 202]. На нашу думку, із запропонованим розумінням наведених термінів можна частково погодитися, проте воно потребує доповнення в тому числі й із урахуванням сучасної вітчизняної форми кримінального процесу, про що нами зазначалося вище.

Варто звернути увагу на те, що в теорії криміналістики відповідний окремий розділ криміналістики вченими-криміналістами називається по-різному, зокрема «криміналістична методика», хоча в ньому традиційно розглядаються питання лише методики розслідування окремих видів злочинів.

Так, виходячи з форми кримінального процесу, яка була на той час, В.Г. Танасевич визначав криміналістичну методику як систему рекомендованих з метою розкриття злочинів і запобігання їм методів і прийомів із послідовного дослідження обставин учинення злочину й викриття осіб, котрі його вчинили, яка грунтується на розроблених криміналістикою загальнотеоретичних положеннях, науково-технічних засобах і тактичних прийомах [27, с. 171].

На думку В.А. Образцова, криміналістична методика є своєрідним еталоном того, як потрібно діяти слідчому в тих або інших умовах [28, с. 375].

В.П. Бахін писав, що криміналістична методика являє собою систему наукових положень і розроблених на їх основі практичних рекомендацій з оптимального проведення розслідування злочинів [29, с. 3]. При цьому він слушно зазначав, що криміналістичні методики $€$ засобом практичної реалізації положень (рекомендацій) криміналістичної техніки і криміналістичної тактики [30, с. 101].

P.C. Бєлкін, ототожнюючи криміналістичну методику з методикою розслідування окремих видів злочинів та з окремою методикою, вважав, що криміналістична методика - це система наукових положень і розроблюваних на їх основі рекомендацій з організації та здійснення розслідування злочинів та запобігання їм [31, с. 101].

Г.А. Матусовський пропонував розглядати криміналістичну методику у двох аспектах: як процес розслідування злочинів, специфічну діяльність уповноважених законом органів та осіб, що здійснюється на підставі застосування засобів криміналістичної техніки, прийомів слідчої тактики, методів розслідування певних видів; як розділ науки криміналістики, що містить систему комплексних криміналістичних рекомендацій із виявлення, розслідування й профілактики окремих видів злочинів. Саме у взаємозв’язку цих двох напрямів - практичного й теоретичного, на його думку, ця категорія виявляє своє призначення [4, с. 358]. Варто звернути увагу на те, що практичний аспект методики, запропонований Г.А. Матусовським, піддавався обгрунтованій критиці [32, с. 17; 33, с. 484-485].

Криміналістична методика визначається також і як інформаційна модель наукових положень і розроблюваних на їх основі практичних реко- 
мендацій з організації та здійснення розкриття, розслідування злочинів і запобігання їм [34, с. 109].

B.M. Салтевський визначав криміналістичну методику як завершальний розділ науки криміналістики, який являє собою систему наукових положень (закономірностей, принципів) і розроблених на їх основі практичних рекомендацій (алгоритмів, програм), що забезпечують оптимальну організацію розслідування окремих видів злочинів і запобігання їм [1, с. 411].

Отже, підсумовуючи викладене, зазначимо, що спільним для всіх наведених визначень $є$ те, що криміналістична методика зазначеними вченими розглядається як відповідний розділ криміналістики, як методика розслідування певної групи (виду) злочинів, як методика розслідування конкретного злочину.

Варто звернути увагу не те, що в теорії криміналістики поряд із терміном «криміналістична методика» вживається також і термін «криміналістична методика розслідування окремих видів злочинів» як розділ криміналістики, що вивчає загальні закономірності організації й розслідування злочинів, розробляє на їх основі з урахуванням вимог кримінального та кримінально-процесуального законодавства науково-методичні рекомендації з виявлення, розкриття й розслідування злочинів певного виду, групи, а також окремих злочинів з урахуванням їх специфіки [35, с. 339].

Виходячи з порівняльного аналізу змісту цих категорій, що викладається в криміналістичній літературі, можемо зробити висновок, що ці терміни більшістю криміналістів необгрунтовано ототожнюються.

У теорії криміналістики поряд із терміном «методика» останніми роками використовується й термін «технологія», що є предметом широких наукових дискусій [36, с. 22; 37, с. 4-9; 38, с. 67]. На нашу думку, у криміналістиці більш обгрунтованим є вживання терміна «методика», що більше відповідає предмету, завданням криміналістики, змісту цієї діяльності.

У криміналістиці широко вживається й термін «окрема криміналістична методика», який, на думку В.А. Журавля, охоплює не лише методи (систему методів), прийоми та засоби, а й рекомендації (поради) слідчому й судді 3 найбільш оптимальної, раціональної організації процесу розслідування певних видів злочинів і судового розгляду кримінальних проваджень [33, с. 189]. Окрема криміналістична методика, на думку автора, - це інформаційно-пізнавальна модель, у якій відображено комплекси методів, засобів, прийомів і рекомендацій типізованого характеру, викладених в описовій або формалізованій формі, щодо раціональної організації процесу збирання, оцінювання й використання доказової інформації стосовно специфіки вчинення та розслідування різних злочинних виявів і судового розгляду кримінальних справ [39, с. 198].

Загалом погоджуючись із таким визначенням, уважаємо, що воно $є$ неповним, оскільки не відбиває діяльність усіх суб’єктів сторін криміналістичного провадження.

Для розкриття питання про співвідношення криміналістичної методики та організації важливим є визначення структури криміналістичної методики. При цьому варто зазначити, що неповне відображення діяльності сторін кримінального провадження (сторони обвинувачення і сторони захисту) й суду в криміналістичній методиці, а також необгрунтоване ототожнення криміналістичної методики як родового поняття з методикою розслідуван- 
ня окремих видів злочинів як окремого поняття призвело до того, що більшістю криміналістів структура криміналістичної методики необгрунтовано розкривається лише через структуру методики розслідування окремих видів злочинів. Хоча й серед криміналістів сьогодні немає єдності думок щодо ї структури. Дискусіі із цього питання докладно викладені в криміналістичній літературі $[39 ; 40 ; 41 ; 42 ; 33 ; 43 ; 44 ; 45 ; 46$ тощо].

Більшістю криміналістів виокремлюються такі структурні елементи методики розслідування окремих видів злочинів: криміналістична характеристика злочину; особливості початку кримінального провадження й обставини, які підлягають установленню під час розслідування; типові слідчі ситуації та типові слідчі версії, що висуваються й перевіряються в цих ситуаціях на початковому та подальшому етапах розслідування, й відповідні їм алгоритми розслідування; організаційно-тактичні засади проведення слідчих (розшукових) та інших процесуальних дій на початковому та подальшому етапах розслідування; особливості використання спеціальних знань у ході розслідування; особливості взаємодії слідчого з правоохоронними й іншими державними органами, підприємствами, установами, організаціями та громадянами під час розслідування [47, с. 19].

Підсумовуючи викладене із цього питання, вважаємо доцільним 3 урахуванням сучасної форми кримінального процесу, іï трьох основних кримінальних процесуальних функцій (обвинувачення, захист, вирішення справи (правосуддя)), а також закріплення в чинному Кримінальному кодексі України нових видів злочинів і вдосконалення сучасної злочинності розглядати таку систему криміналістичної методики: криміналістична методика (як родове поняття); такі ї видові поняття: а) криміналістична методика обвинувачення, куди включаються такі іï підвиди та окремі методики: криміналістичні методики розслідування окремих видів злочинів, криміналістична методика процесуального керівництва досудовим розслідуванням, криміналістичні методики державного обвинувачення на різних стадіях процесу й за різними категоріями кримінальних проваджень чи видами злочинів; б) криміналістична методика захисту, куди включаються такі їі підвиди та окремі методики: криміналістичні методики захисту на різних стадіях процесу й за різними категоріями кримінальних проваджень чи видами злочинів; в) криміналістична методика судового розгляду, куди включаються як іiі підвиди та окремі криміналістичні методики судового розгляду на різних стадіях кримінального процесу чи за окремими категоріями кримінальних проваджень чи видами злочинів.

У системі криміналістичних методик доцільно виокремлювати криміналістичні методики одиничні й комплексні, а також за такими критеріями: за особою злочинця; за особою потерпілого; за часом учинення злочину тощо. Кожна із запропонованих методик потребує розробки своєї структури.

Варто зазначити, що запропонована система криміналістичних методик потребує й уточнення предмета криміналістики, що є самостійним предметом дослідження.

Виходячи 3 такого розуміння криміналістичної методики, ї видів і структури, важливим є з'ясування ї співвідношення з терміном «організація розслідування». Термін «організація» є одним із найпоширеніших у криміналістичній науці. Він уживається в таких термінологічних словоспо- 
лученнях, як «організація розслідування», «організація й методика розслідування», «організація слідства», «організація проведення окремої слідчої дії, «організація й тактика слідчої дії тощо, що дає підстави зарахувати його до фундаментальних категорій криміналістики.

У наукових працях українських і зарубіжних процесуалістів і криміналістів, зокрема В.П. Бахіна, Р.С. Бєлкіна, А.Ф. Волобуєва, В.О. Коновалової, В.С. Кузьмічова, О.М. Ларіна, В.Ю. Шепітька, М.П. Яблокова та ін., які досліджували окремі аспекти організації діяльності з розкриття й розслідування злочинів, пропонуються визначення понять «організація розслідування злочину», «організація слідчої дії, «організація слідства». Разом із тим необхідно констатувати відсутність єдності думок щодо визначення цих понять, ї сутності та змісту, місця «організації в криміналістиці. До того ж результати аналізу криміналістичної літератури показали, що в багатьох наукових дослідженнях, навіть монографічного рівня, автори, використовуючи термін «організація», нерідко не розкривають його поняття і змісту [1; 48 тощо]. Вищевикладене негативно впливає як на теоретичні дослідження, так і на практичну діяльність із розкриття й розслідування злочинів.

Зважаючи на те, що діяльність із розкриття й розслідування злочинів $є$ складником людської діяльності, а саме одним із ї видів, методологічною основою для формулювання поняття «організація» $€$ філософський діяльнісний підхід до розкриття будь-яких аспектів людської діяльності, який у теорії кримінального процесу та криміналістики вперше застосовувався А.Я. Дубинським [49, с. 47] і набув подальшого розвитку в роботах інших процесуалістів і криміналістів $[50 ; 51 ; 51]$, а також поняття «організація людської діяльності» та його сутнісні структурні елементи.

У теорії та практиці людської діяльності поняття «організація» трактується досить широко: як дія за значенням організувати, організовувати й організуватися; як об’єднання людей, суспільних груп, держав на базі спільності інтересів, мети, програми дій тощо; як сукупність людей, груп, об'єднаних для досягнення якої-небудь мети, вирішення якого-небудь завдання на основі принципів поділу праці, поділу обов'язків та ієрархічної структури, громадське об'єднання, державна установа; як складова частина управління, сутність якої полягає в координації дій окремих елементів системи, досягненні взаємної відповідності функціонування ії частин; як особливості будови, устрій чого-небудь, структура; як фізичні й психічні особливості окремої особи; як комплекс заходів, зміст яких полягає в координації дій окремих елементів системи [53, с. 853]; як процес або сукупність дій, що зумовлюють утворення й удосконалення взаємозв'язків між частинами цілого [54, с. 935]. Таке широке трактування цього терміна можна пояснити, виходячи з його етимологічного значення: «організація» $€$ похідним від «орган» - частина організму, що має визначену будову i спеціальне призначення; засіб, знаряддя; періодичне видання [53, с. 852]. Водночас варто зазначити, що кожна дія має свій результат, і тому результатом діï зі значенням «організувати» буде саме «організація» як певний упорядкований об’єкт із відповідною структурою.

Поняття «організація» тісно пов'язане із суспільним життям - створенням і функціонуванням певних сукупностей людей (їхніх груп). У розумінні об’єктивного явища, властивого всім керованим соціальним об'єктам, понят- 
тя «організація» використовується поряд із поняттям «управління», розуміється як його складова частина, функція. У свою чергу, термін «управління» розуміється як діяльність органів влади; сукупність приборів, пристосувань, пристроїв, за допомогою яких управляється хід машини, механізму; великий підрозділ якої-небудь установи, велика адміністративна установа [55, с. 440]; дія за значенням управляти (виконувати, завершувати якусь роботу, справу; надавати кому-небудь належного вигляду, задовольняти його потреби; доводити до ладу що-небудь; те саме, що керування) [53, с. 1511].

У теорії управління «організація» розглядається в статиці (як стан системи управління) та динаміці (як функція процесу управління) [56, с. 176].

Під станом системи управління розуміють аі впорядкованість і цілісність у функціональному і структурному відношенні [57, с. 97], iі внутрішню структуру [58, с. 188]. Організацію як функцію управління розглядають як свідому діяльність, спрямовану на упорядкування стану тих чи інших соціальних утворень [57, с. 97], визначають їі як центральну в системі функцій управління [59, с. 14], виділяють як організацію процесу управління загалом, так і організацію окремих його стадій.

Хоча з вищенаведеного й убачається тісний зв’язок між поняттями «організація» та «управління», разом із тим дослідники вказують, що управління являє собою цілеспрямовану діяльність, яка організовує й координує спільні зусилля учасників процесу управління в рамках уже наявної та певним чином організованої структури [60, с. 10]; метою управління є досягнення запрограмованого стану системи, водночас метою організації впорядкування та узгодження зв'язків між елементами системи [34, с. 8]. Разом із тим організацію управління визначають як створення системи управління або внесення прогресивних змін у побудову й порядок функціонування раніше утвореної діючої системи управління [61, с. 609].

Як слушно зазначають окремі науковці, термін «організація» щодо певного виду людської діяльності доцільно розглядати як:

- власне організацію (організація в статиці),

- діяльність з упорядкування організації (організація організації),

- діяльність з упорядкування процесу управління діяльністю організаціі (організація управління організацією) [62, с. 21].

Розглядати організацію слідства як певну систему, тобто в статиці, пропонують О.І. Михайлов, Л.О. Соя-Сєрко, А.Б. Соловйов [63, с. 8-9], але науковцями не розкриваються такі характеристики зазначеної системи, як елементи, їі структура, взаємозв'язки між елементами системи та їх характер тощо. Зазначену організацію, відповідно до теорії управління, можна визначити як організацію управління в слідчій діяльності.

Організація як одна 3 функцій управління - як діяльність з упорядкування (налагодження) системи управління - має на меті підвищення рівня організованості цієї системи шляхом створення, підтримання функціонування та подальшого розвитку організаційних структур управління; здійснення організуючого впливу суб'єкта на об'єкт управління з метою впорядкування й узгодженості зв'язків між елементами системи; забезпечення взаємодії частин системи тощо.

Поняття «організація» в статиці та як діяльність з упорядкування системи управління в криміналістиці не використовуються, оскільки виходять за межі 
iï предмета, вивчаються теорією управління органів Національної поліції, кримінальним процесуальним правом, науковою організацією праці тощо.

Організація як діяльність з упорядкування процесу управління (його окремих стадій) полягає в забезпеченні оптимальних умов для прийняття й реалізації управлінських рішень у діяльності певної організації. У цьому аспекті більшість криміналістів і процесуалістів використовують термін «організація» під час визначення термінів «організація розслідування», «організація розслідування злочину», «організація слідства», «організація проведення слідчої дії» й інших термінологічних словосполучень.

$\mathrm{У}$ юридичній літературі мають місце пропозиції розглядати організацію розслідування злочинів як створення структури розслідування (Д.О. Влезько, С.І. Гріцаєв, В.Д. Зеленський) і як забезпечення розслідування. Позиції, що організація є забезпеченням, дотримуються Р.С. Бєлкін, А.Ф. Волобуєв, О.М. Ларін, І.П. Можаєва, В.В. Степанов, В.Ю. Шепітько, М.П. Яблоков та ін. Розробником цього підходу в криміналістиці є Р.С. Бєлкін, який цілком обгрунтовано, на нашу думку, вказує на те, що будь-яка організаційна діяльність $є$ забезпеченням досягнення певних цілей і визначає організацію конкретного акту розслідування злочинів як комплекс заходів зі створення оптимальних умов для визначення й використання найбільш ефективних і доцільних у конкретній слідчій ситуації рекомендацій криміналістичної методики (курсив наш - М. П. та Д. С.) з метою досягнення максимальних результатів за мінімальних витрат часу, засобів і сил [64, с. 442].

Термін «забезпечення» має значення дії зі значенням «забезпечувати»- постачати щось у достатній кількості, задовольняти кого-, що-небудь у якихось потребах; надавати кому-небудь достатні матеріальні засоби до існування; створювати надійні умови для здійснення чого-небудь, гарантувати щось. Через призму дослідження найбільший інтерес становить визначення «забезпечення» як створення надійних умов для здійснення чого-небудь. Семантичний аналіз понять, пов'язаних із терміном «організація», дає змогу побудувати таку конструкцію: «організація - забезпечення - створення надійних умов».

Зазначимо, що, зважаючи на пропозиції Р.С. Бєлкіна, що залишаються дотепер актуальними, чітко розрізняти рівні організації розслідування як діяльності, можна виділити два самостійні напрями використання терміна «організація» в криміналістиці: 1) тактичний рівень організації розслідування - це організація проведення окремої слідчої дії або організаційно-технічного заходу в межах конкретного акту розслідування - реалізується в криміналістичній тактиці як розділі науки криміналістики; 2) організація конкретного акту розслідування злочину - методичний рівень, що реалізується в останньому розділі криміналістики - криміналістичній методиці або методиці розслідування окремих видів злочинів [64, с. 434-435].

Результати системного аналізу запропонованих у юридичній літературі визначень цього поняття дають підстави для висновку, що в криміналістичній методиці організаційний аспект є невід'ємним, про що прямо вказується в більшості його визначень.

Разом із тим варто зазначити, що до визначення співвідношення організації та криміналістичної методики склалося декілька основних підходів. Так, одна група вчених, зокрема Б.Л. Зотов, О.Н. Колєсніченко, І.Ф. Пан- 
тєлєєв, М.О. Сєліванов та ін., не використовуючи термін «організація розслідування», включають до змісту методики елементи суто організаційного характеру, наприклад, особливості планування розслідування залежно від виду злочину тощо. Іншу позицію займають О.М. Васильєв, І.А. Возгрін, Д.Я. Мирський, С.П. Мітрічєв, В.Г. Танасевич та інші вчені, виділяючи питання організації розслідування, організаційної діяльності слідчого, організаційних заходів у предмет та окремий розділ криміналістичної методики. Так, О.М. Ларін зазначає, що до криміналістичної методики повинна входити «теорія планування та організаціі розслідування» [65, с. 22].

P.C. Бєлкін уважає такі підходи необгрунтованими й висловлює думку, що питання організації розслідування на рівні криміналістичної методики повинні являти собою органічну частину всіх їі елементів, але не виділятися в самостійний підрозділ або теорію [51, с. 437].

На нашу думку, з представленими позиціями повною мірою погодитися не можна, оскільки, по-перше, варто чітко розмежовувати криміналістичну методику розслідування конкретного виду злочину, яка має певну структуру (включає в себе криміналістичну характеристику злочину, типові слідчі ситуації, тактику провадження першочергових слідчих (розшукових) дій i слідчих (розшукових) дій на подальшому етапі розслідування та інші елементи) та розробляється для цілеспрямованої, активної боротьби зі злочинністю, провадження розслідування й запобігання окремим видам злочинів, та організаційні заходи, які здійснюються як допоміжна, забезпечувальна діяльність у процесі діяльності з розкриття й розслідування злочинів.

По-друге, ми вважаємо позицію Р.С. Бєлкіна цілком обгрунтованою, оскільки організація як діяльність із забезпечення, створення надійних умов для реалізації окремих елементів криміналістичної методики $є$ органічною частиною їх здійснення. Так, наприклад, тактику провадження першочергових слідчих (розшукових) дій неможливо здійснити без мінімальної організації цих заходів. Разом із тим деякі види організаційної діяльності слідчого із забезпечення процесу розслідування мають суттєве значення для його ефективності й закономірно включені до структури криміналістичної методики як їі окремі, самостійні елементи (наприклад, особливості планування розслідування, особливості взаємодії слідчого тощо).

Усе вище наведене щодо організації як діяльності із забезпечення, створення надійних умов для реалізації окремих елементів криміналістичної методики розслідування в повній мірі стосується й усіх видових та окремих й комплексних методик.

Висновки. Отже, на підставі проведеного нами дослідження можна дійти висновку, що у криміналістиці доцільно вживати термін «організація кримінального провадження» як родове поняття та відповідні видові поняття (організація досудового розслідування, організація захисту, організація окремої слідчої (розшукової) дії тощо).

Терміни «організація кримінального провадження» та «криміналістична методика» є окремими, самостійними криміналістичними категоріями, поняття, а також сутність і завдання яких суттєво різняться. Водночас у криміналістичній методиці організаційний аспект є невід’ємним. Так, організація є невід’ємною частиною діяльності з реалізації окремих елементів будь-якої криміналістичної методики, а окремі види організаційної діяльно- 
сті слідчого із забезпечення процесу розслідування, прокурора, захисника, суду, експерта та ін. із забезпечення їхної діяльності через своє важливе значення для їх ефективності включені до структури відповідної криміналістичної методики як їі структурні елементи.

Кожна із криміналістичних методик потребує постійного вдосконалення, а окремі - розробки відповідно до вимог часу, у тому числі і їх організаційної складової, що потребує подальших наукових пошуків.

\section{Література}

1. Салтевський М.В. Криміналістика (у сучасному викладі) : [підручник] / М.В. Салтевський. - К. : Кондор, 2008. - 594 с.

2. Криміналістика : [навчальний посібник] / за ред. А.Ф. Волобуєва. - К. : КНТ, 2011. - 504 с.

3. Криміналістика : [підручник] / [В.В. Пясковський, Ю.М. Чорноус, А.В. Іщенко та ін.]. К. : Цент учбової літератури, 2015. - 544 с.

4. Криміналістика : [підручник] / [кол. авт.: В.М. Глібко, А.Л. Дудніков, В.А. Журавель та ін.] ; за ред. В.Ю. Шепітька. - К. : Видавничий Дім «Ін Юре», 2001. - 684 с.

5. Тіщенко В.В. Теоретичні і практичні основи методики розслідування злочинів : [монографія] / В.В. Тіщенко. - Одеса : Фенікс, 2007. - 260 с.

6. Корноухов В.Е. Теоретические проблемы методики расследования преступлений / B.Е. Корноухов / / Ученые-криминалисты и их роль в совершенствовании научных основ уголовного судопроизводства : матер. вузов. юб. науч.-практ. конф., посвященной 85-летию со дня рождения проф. Р.С. Белкина и юбилеям его учеников : в 2 ч. - М. : Акад. упр. МВД России, 2007. - C. 421-425.

7. Криминалистика : [учебник] / под ред. Е.П. Ищенко. - М. : Юрид. фирма «Контракт»: ИНФРА-М, 2005. - 784 с.

8. Шепитько В.Ю. Криминалистика : [курс лекций] / В.Ю. Шепитько. - Х. : ООО «Одиссей», 2006. - 368 с.

9. Шавер Б.М. Об основных принципах частной методики / Б.М. Шавер / / Социалистическая законность. - 1938. - № 1. - С. 42-56.

10. Зеленецкий В.С. Общая теория борьбы с преступностью / В.С. Зеленецкий. - Х. : Основа, 1994. - Т. 1 : Конституционные основы. - 1994. - 321 с.

11. Варфоломеева Т.В. Криминалистика и профессиональная деятельность защитника : [монография] / Т.В. Варфоломеева. - К. : Вища шк., 1987. - 151 с.

12. Ароцкер Л.Е. Основные вопросы тактики и методики судебного разбирательства / Л.Е. Ароцкер / / Настольная книга судьи (рассмотрение уголовных дел в суде первой инстанции) / [кол. авт.]. - М. : Юрид. лит., 1972. - С. 150-171.

13. Когутич I.I. Окремі аспекти криміналістичної методики судового розгляду кримінальних справі / I.I. Когутич / / Вісник Львівського університету. Серія «Юридична». - 2007. Вип. 43. - С. 298-307.

14. Когутич I.I. Використання сучасних знань та засобів криміналістичної тактики і методики під час розгляду кримінальних справ у суді : [монографія] / I.I. Когутич. - Львів : Тріада плюс, 2009. - 448 с.

15. Великий тлумачний словник сучасної української мови / уклад. іголовн ред. В.Т. Бусел. - К. : Ірпінь : ВТФ «Перун», 2009. - 1736 с.

16. Громов В.И. Методика расследования преступлений. Руководство для органов милиции и уголовного розыска / В.И. Громов. - М., Изд. 1, 1929. - 114 с.

17. Голунский С.А. Криминалистика: методика расследования отдельных видов преступлений / С.А. Голунский, Б.М. Шавер ; Ин-т права АН СССР ; под ред. А.Я. Вышинского. - М. : Юрид. изд-во НКЮ СССР, 1939. - 372 с.

18. Кисленко С.Л. Судебное следствие: Состояние и перспективы развития / С.Л. Кисленко, В.И. Комиссаров. - М. : Юрлитинформ, 2003. - 176 с. 
19. Баев О.Я. Основы криминалистики : [курс лекций] / О.Я. Баев. - 2-е изд., перераб. и доп. - М. : Экзамен, 2003. - 318 с.

20. Руководство для государственных обвинителей: Криминалистический аспект деятельности. / [В.С. Бурданова, В.И. Иванов, К.А. Корсаков, О.Н. Коршунова, С.К. Питерцев, Е.Б. Серова, А.А. Степанов] ; науч. ред. О.Н. Коршунова. - 2-е изд., перераб. - СПб., 2002. - Ч. II : Особенности поддержания государственного обвинения по делам об убийствах. - 2002. - 160 с.

21. Рубис А.С. Криминалистическое обеспечение деятельности прокурора в сфере борьбы с преступностью / А.С. Рубис. - Минск : БГУ, 2005. - 271 с.

22. Бородин С.В. Методологические принципы профессиональной защиты в уголовном судопроизводстве России: от индивидуального опыта к научной концепции методики / С.В. Бородин / / Засади кримінального судочинства та їх реалізація в законотворчій і правозастосовній діяльності : тези доп. та повідомл. наук.-практ. конф. (м. Київ, 3 квіт. 2009 р.). - К. : Атіка, 2009. - C. 70-73.

23. Гапон А.О. Методика профессиональной защиты по делам о ДТП на стадии досудебного производства / А.О. Гапон // Транспортное право: практич. и информ. изд. - М. : ИГ «рист». - 2010. - № 2. - С. 2-4.

24. Щур Б.В. Теоретичні основи формування та застосування криміналістичних методик : [монографія] / Б.В. Щур. - Х. : Харків юридичний, 2010. - 320 с.

25. Криминалистика : в 3 т. / под ред. Р.С. Белкина, В.Г. Коломацкого, И.М. Лузгина. М. : Акад МВД РФ, 1995. - Т. 1 : История, общая и частные теории. - 1995. - 345 с.

26. Журавель В. Окрема криміналістична методика: поняття та сфера застосування / В. Журавель / / Вісник академії правових наук України : зб. наук. пр. / редкол.: В.Я. Тацій та ін. - Х. : Право, 2011. - № 2 (65). - С. 202-214.

27. Советская криминалистика. Теоретические проблемы. - М. : Юрид. лит., 1978. - 192 с. 28. Образцов В.А. Криминалистика / В.А. Образцов ; под ред. В.А. Образцова. M., 1995. - 592 c.

29. Бахин В.П. Криминалистическая методика : [лекция] / В.П. Бахин. - К., 1999. - 26 с. 30. Бахін В.П. Криміналістика : [курс лекцій] / В.П. Бахін, І.В. Гора, П.В. Цимбал. Ірпінь : Акад. ДПС України, 2002. - Ч. 1. - 2002. - 356 с.

31. Белкин Р.С. Криминалистическая энциклопедия / Р.С. Белкин. - 2-е изд., доп. - М. : Мегатрон XXI, 2000. - 334 с.

32. Волобуєв А.Ф. Проблеми методики розслідування розкрадань майна в сфері підприємництва / А.Ф. Волобуєв. - Х. : Вид-во Ун-ту внутр. справ, 2000. - 336 с.

33. Журавель В.А. Вибрані твори / В.А. Журавель. - Х. : Агенція «Апостіль», 2016. - 704 с.

34. Шмонин А.В. Методика расследования преступлений : [учебное пособие] / А.В. Шмонин. - М. : ЗАО Юстицинформ, 2006. - 464 с.

35. Криминалистика : [учебник] / [Л.В. Бертовский и др.] ; под ред.: Е.П. Ищенко, В.И. Комиссарова. - М. : Юристъ, 2007. - 509 с.

36. Тіщенко В.В. Криміналістичні технології в теорії і практиці розслідування / В.В. Тіщенко // Актуальні проблеми держави і права. - 2008. - Вип. 44. - С. 18-24.

37. Щур Б.В. Слідчі технології в криміналістиці: постановка проблеми / Б.В. Щур // Криминалист первопечатный: межд. наук.-практ. юрид. журн. - 2010. - № 1. - С. 4-9.

38. Моїсєєв О.М. Експертні технології: теорія формування і практика застосування : [монографія] / О.М. Моїсєєв. - Х. : Вид. агенція «Апостіль», 2011. - 424 с.

39. Журавель В.А. Окремі методики в системі криміналістичних знань / В.А. Журавель / / Науковий вісник Львівської комерційної академії. Серія «Юридична». - 2015. - Вип. 1. C. $187-200$.

40. Журавель В.А. О структуре частной криминалистической методики / В.А. Журавель / / Криминалистика и судебная экспертиза : респ. межвед. науч. сб. - К. : Вища школа, 1995. - Вып. 47. - С. 62-67.

41. Журавель В.А. Сучасні концепції формування окремих криміналістичних методик розслідування злочинів / В.А. Журавель / / Вісник Академії правових наук України. - 2007. № 2. - C. $177-186$.

42. Журавель В.А. Окрема криміналістична методика розслідування злочинів: форма, структура, зміст / В.А. Журавель // Теорія та практика судової експертизи і криміналістики : зб. наук. праць. - Х. : Право, 2007. - Вип. 7. - С. 17-24. 
43. Тищенко В.В. О новых тенденциях в криминалистической методике расследования преступлений / В.В. Тищенко / / Наукові праці Одеської національної юридичної академії / голов. ред. С.В. Ківалов ; МОН України, ОНЮА. - Одеса : Юрид. л-ра, 2009. - Т. 8. C. $260-269$.

44. Тищенко В.В. Криминалистическая методика расследования: современное состояние и перспективы развития / В.В. Тищенко / / Наукові праці Національного університету «Одеська юридична академія». - 2010. - Т. 9. - С. 170-181.

45. Тищенко В.В. Формирование теоретических основ криминалистической методики расследования преступлений: проблемы, тенденции / В.В. Тищенко // Проблемы уголовного процесса, криминалистики и судебной экспертизы. - 2014. - № 3. - С. 17-24.

46. Тіщенко В.В. Вибрані праці / В.В. Тіщенко. - Одеса : Видавничий дім «Гельветика», 2017. - 436 c

47. Розслідування окремих видів злочинів : [навчальний посібник] / [О.В. Бишевець, М.А. Погорецький, Д.Б. Сергєєва та ін.] ; за ред. М.А. Погорецького та Д.Б. Сергєєвої. - К. : Алерта, 2015. - 536 с.

48. Сас В.А. Організація і тактика слідчих дій при розслідуванні злочинів, вчинених засудженими до позбавлення волі : [монографія] / В.А. Сас. - К. : НТВ «Правник», 2004. - 240 с.

49. Дубинский А.Я. Понятие, структура и содержание уголовно-процессуальной деятельности / А.Я. Дубинский / / Проблемы социалистической законности. - Х., 1989. - Вып. 24. - С. 46-52.

50. Погорецький М.А. Функціональне призначення оперативно-розшукової діяльності у кримінальному процесі : [монографія] / М.А. Погорецький. - Х. : Арсіс, ЛТД, 2007. - 576 с.

51. Сергєєва Д.Б. Щодо визначення поняття «організація» в криміналістичній науці / Д.Б. Сергєєва / / Боротьба з організованою злочинністю і корупцією (теорія і практика). 2012. - № 2 (28). - С. 232-240.

52. Погорецький М. Щодо визначення поняття «організація» у криміналістичній науці та його співвідношення із криміналістичною тактикою / M. Погорецький, Д. Сергєєва / / Вісник Київського національного університету імені Тараса Шевченка. Серія «Юридичні науки». 2012. - Вип. 93. - С. 14-17.

53. Великий тлумачний словник сучасної української мови (з дод. і допов.) / уклад. і голов. ред. В.Т. Бусел. - К. ; Ірпінь : ВТФ «Перун», 2005. - 1728 с.

54. Советский энциклопедический словарь. - М. : Советская энциклопедия, 1980. - 1600 с.

55. Словарь русского языка: 52000 слов / сост. С.И. Ожегов ; под общ. ред. академ. С.П. Обнорского. - 3-е изд. - М. : Гос. изд-во иностранных и национальных словарей, 1953. - 848 с.

56. Організація управління в органах внутрішніх справ : [монографічне дослідження] / [Ю.Л. Титаренко, В.П. Філонов, В.Д. Сущенко та ін.] ; за ред. Ю.Л. Титаренка. - Донецьк : ДІВС при Донецькому державному університеті, 1999. - 364 с.

57. Плішкін В.M. Теорія управління органами внутрішніх справ : [підручник] / В.М. Плішкін ; за ред. Ю.Ф. Кравченка. - К. : НАВСУ, 1999. - 702 с.

58. Основы управления в органах внутренних дел : [учебник] / [Н.И. Буденко, Г.П. Герт, В.Р. Кисин и др.] ; под ред. А.П. Корнеева. - М. : Щит-М, 1996. - 343 с.

59. Астафьев Л.В. Организация как функция управления (на материалах управленческой деятельности начальников городских и районных органов внутренних дел) : автореф. дисс. ... канд. юрид. наук : спец. 12.00 .10 / Л.В. Астафьев. - М., 1987. - 23 с.

60. Можаева И.П. Организационные основы криминалистической деятельности : автореф. дисс. ... канд. юрид. наук : спец. 12.00.09 / И.П. Можаева. - Саратов, 2003. - 26 с.

61. Большой экономический словарь / под. ред А.Н. Азрилияна. - М. : Институт новой экономики, 2002. - 1280 с.

62. Шеломенцев В.П. Поняття організації оперативно-розшукової діяльності / В.П. Шеломенцев, М.А. Погорецький / / Кримський юридичний вісник. - 2010. - Вип. 1 (8). - Ч. І. - С. 18-28.

63. Михайлов А.И. Научная организация труда следователя / А.И. Михайлов, Л.А. Соя-Серко, А.Б. Соловьев ; Всесоюз. ин-т по изуч. причин и разраб. мер предупр. преступности. - М. : Юрид. лит., 1974. - 168 с.

64. Белкин Р.С. Курс криминалистики : в 3 т. / Р.С. Белкин. - М. : Юристъ, 1997. - Т. 2 : Частные криминалистические теории. - 1997. - 464 с.

65. Ларин А.М. Проблема общей методики расследования преступлений / А.М. Ларин. M., 1976. - 168 c. 


\section{Ано о а ці я}

Погорецький М. А., Сергеєва Д. Б. Співвідношення криміналістичної методики й організації кримінального провадження. - Стаття.

У статті з урахуванням сучасної форми кримінального процесу, іï трьох основних кримінальних процесуальних функцій (обвинувачення, захист, вирішення справи (правосуддя)), а також закріплення в чинному Кримінальному кодексі України нових видів злочинів і вдосконалення сучасної злочинності пропонується система криміналістичної методики. На підставі проведеного аналізу вітчизняних і зарубіжних наукових джерел, присвячених питанням криміналістичної методики й організації, запропоновано авторське бачення їх співвідношення.

Ключові слова: розслідування злочинів, організація розслідування, криміналістична методика.

\section{Аннот а ци я}

Погорецкий Н. А., Сергеева Д. Б. Соотношение криминалистической методики и организации уголовного производства. - Статья.

С учетом современной формы уголовного процесса, ее трех основных уголовных процессуальных функций (обвинение, защита, решение дела (правосудие)), а также закрепления в действующем Уголовном кодексе Украины новых видов преступлений и совершенствования современной преступности предлагается система криминалистической методики. На основании проведенного анализа отечественных и зарубежных научных источников, посвященных вопросам криминалистической методики и организации, предложено авторское видение их соотношения.

Ключевые слова: расследование преступлений, организация расследования, криминалистическая методика.

\section{S u m m a r y}

Pohoretskyi M. A., Serhieieva D. B. The correlation of forensic methodology and organization of criminal proceedings. - Article.

Given the current form of criminal procedure, it contains three main criminal procedural functions (prosecution, defense, settlement of the case (Justice) and consolidation in the current Criminal Code of Ukraine of new types of crime and improvement of modern crime, author proposed the system of criminalistic methods. Based on the analysis of domestic and foreign scientific sources on the issues of criminalistic methods and organization, author proposed vision of their interrelation.

Key words: investigation of crimes, organization of investigation, criminalistic methods. 